DOI 10.31558/2518-7953.2019.1.6

УДК 346.21

Л. М. Дороченко
дочент кафедри ичивільного права і прочесу

Донечького національного університету

імені Василя Стуса,

канд. юрид. наук, дочент

\title{
СПОСОБИ УСУНЕННЯ ДЕДЛОКА ЯК РІЗНОВИДУ КОРПОРАТИВНИХ КОНФЛІКТІВ
}

Ключові слова: дедлок, корпоративний тупик, статутний капітал, корпоративні підприємства, засновники, корпоративний конфлікт.

За останні роки корпоративні конфлікти стали центром уваги судової практики та правників-науковців. Як зауважує О. В. Бігняк, підгрунтям для виникнення такого роду конфліктів (зокрема, недружніх поглинань, прийняття незаконних судових рішень) $є$ недосконалість правового регулювання корпоративних відносин, відсутність реформування корпоративного законодавства та ефективної доктрини корпоративного права, низька якість локальних актів господарських товариств $[1$, с. 261]. Нині в законодавстві відсутне поняття «корпоративний конфлікт», недостатньо розкритим воно залишається і в національній правовій доктрині.

Корпоративні конфлікти - це спори, які виникають між господарським товариством, його учасниками (акціонерами), менеджментом. Останнім часом активними учасниками таких конфліктів стають й бенефіціари компаній. В основі корпоративних конфліктів, як правило, полягають протиріччя між інтересами мажоритарних та міноритарних акціонерів, акціонерів і управлінців, бенефіціарів і менеджменту компанії.

Одним 3 поширених різновидів корпоративних конфліктів $є$ той, що позначається серед юристів-корпоративістів та представників менеджерського складу великих компаній терміном «дедлок». Дедлок (від англ. - deadlock - тупик, безвихідь) - це стан, конфліктна ситуація, коли засновники корпоративних підприємств, відносини між якими $є$ антагоністичними, не можуть розв'язати цю конфліктну ситуацію, тому що первісно все поділили порівну, тобто володіють рівною кількістю голосів. Якщо в інших конфліктах можна було передбачити можливість настання негативного сценарію всередині товариства для його учасників, то в товаристві, де з часом має місце дедлок, ніхто з учасників не готовий до такої ситуації і не передбачав іiі. У цьому випадку на етапі створення товариства його засновники поводять себе необачливо, беруть зобов'язання і покладаються на чесне слово один одного, їх відносини мають фідуціарний характер. Статут- 
ний капітал сформований внесками 50 на 50 відсотків і засновники на момент створення товариства сподіваються на збереження безконфліктних відносин й надалі. Може існувати ситуація, коли учасники не обмежуються рівним поділом часток у статутному капіталі, і надають певним особам право вето, призначають їх на керівні посади в компанії і все це юридично оформлюють (це може бути викликано відсутністю знань в галузі права, власною необачністю) [2, с. 40]. Такі дії згодом сприяють виникненню можливості зловживання правом, виникненню вищеназваних корпоративних конфліктів.

У юридичній науці значну увагу корпоративним конфліктам приділено О. М. Вінник, яка ввела поняття корпоративної конфліктології як одного з сучасних напрямів юридичної та правової конфліктології [3, с. 114]. Певну наукову цінність для розробки проблематики корпоративних конфліктів представляють праці окремих авторів, присвячені дослідженню корпоративних спорів і захисту прав учасників господарських товариств (Д. В. Ломакіна [4], Г. В. Полковнікова [5], І. В. Спасибо-Фатєєвої [6]). Разом з тим проблеми щодо такого виду корпоративних конфліктів як дедлок розглядалися лише поруч із загальними питаннями корпоративних конфліктів та досі не одержали належної наукової розробки. Комплексний аналіз відповідних проблем потрібен перш за все для визначення механізмів і способів попередження дедлока та ефективного виходу з корпоративного тупика.

У зв’язку з набранням чинності Закону України «Про товариства з обмеженою та додатковою відповідальністю» (далі - Закон про ТОВ та ТДВ), істотною зміною корпоративного законодавства, яке не принесло очікуваної чіткості у вирішенні питань розв'язання корпоративних конфліктів, відсутністю однакової правозастосовчої практики, а також з урахуванням недостатньої наукової розробки порушених питань є підстави стверджувати про об'єктивну необхідність їх подальшого дослідження.

Наведене вище вказує на актуальність заявленої теми цього дослідження, метою якого є обтрунтування пропозицій з удосконалення законодавства щуодо способів усунення дедлока в корпоративних підприємствах.

На практиці доволі часто виникають ситуації, коли в компаніях, де частка в статутному капіталі складає 50 на 50, між засновниками складаються неприязні відносини i, як наслідок, практично будь-який корпоративний конфлікт повністю паралізує подальше функціонування підприємства і стає тим тупиком, для виходу з якого потрібні спеціальні правові засоби.

Вбачається, що в залежності від специфіки розбіжностей і наявності у засновників (учасників) бажання продовжувати вести справи може бути обрано один зі способів усунення дедлока:

1) виключення учасника з товариства; 
2) ліквідація суб'єкта господарювання;

3) примусовий викуп частки на умовах, визначених в корпоративному договорі.

Перший спосіб виходу з корпоративного тупика - виключення учасника 3 товариства. Відповідно до положень ч. 2 ст. 100 Цивільного кодексу України (далі - ЦК України) учасник товариства у випадках та в порядку, встановлених законом, може бути виключений $з$ товариства [7]. В ч. 13 ст. 24 Закону про ТОВ і ТДВ [8] йдеться тільки про наслідки прийняття загальними зборами учасників рішення про виключення учасника з товариства. Передбачено, що не пізніше 30 днів 3 дня прийняття загальними зборами учасників такого рішення товариство зобов'язане повідомити колишньому учаснику (його спадкоємцю, правонаступнику) вартість його частки. Визначено момент, на який розраховується вартість частки, а саме він визначається станом на день, що передував дню прийняття загальними зборами учасників рішення про виключення учасника 3 товариства. При цьому тільки одна чітка підстава виключення міститься у вищезазначеному Законі, а саме ч. 2 ст. 15 встановлює, що якщо учасник товариства не вніс вклад для погашення заборгованості протягом наданого додаткового строку, виконавчий орган товариства має скликати загальні збори учасників, які можуть прийняти рішення про виключення учасника товариства, який має заборгованість із внесення вкладу. Тобто, чіткого переліку підстав виключення учасника Закон не передбачає. I хоча механізм виключення учасника з товариства повинен був би стати універсальним засобом усунення небажаного учасника, який блокує роботу суб'єкта господарювання, практика з цього приводу неодноманітна. Це обумовлено складністю проблеми. Суду важко визначитися з тим, хто з опонентів правий, а хто - ні, оскільки вони - повноцінні партнери, але мають взаємні претензії та втратили спільну мету при здійсненні господарської діяльності свого товариства.

Іноді використовується схема, за якої до двох учасників, між якими навпіл поділено статутний капітал, приєднується третій, тобто частки стають 33,3 відсотки і два учасника можуть об'єднати свої зусилля і позбавитися засновника, який став на заваді. Оскільки нова судова практика з цього питання ще не сформована, можна це проілюструвати на прикладі одного із спорів, розглянутих судом у 2012 році. Так, позивачем заявлено позовні вимоги про визнання недійсним рішення загальних зборів ТОВ «Вільний» в частині прийняття до складу учасників ТОВ «Вільний» ОСОБИ_4 й перерозподілу часток в статутному фонді та визнання недійсною редакції статуту ТОВ «Вільний», яка була зареєстрована після цих змін. В обгрунтування позову зазначено, що раніше ОСОБА_1 був учасником ТОВ «Вільний», частка в статутному капіталі позивача ТОВ «Вільний» складала 50 відсотків. Іншим учасником товариства також з часткою 50 відсотків був ОСОБА_5. Оскаржуваним рішенням загальних зборів учасників ТОВ «Вільний» за 
пропозицією ОСОБИ_5 до складу учасників ТОВ «Вільний» прийнято ОСОБУ_4; перерозподілено статутний фонд товариства між учасниками товариства: вирішено, що частка кожного з учасників буде складати 33,33 відсотка від загального розміру статутного фонду і проведено державну реєстрацію змін до установчих документів ТОВ «Вільний». Позивач вважав це рішення загальних зборів учасників ТОВ «Вільний» незаконним та таким, що порушує права та законні інтереси позивача, і просив визнати рішення недійсним. Ухвалою господарського суду Запорізької області зупинялось провадження по цій справі до вирішення іншої справи, предметом спору в якій було визнання недійсним іншого рішення зборів учасників ТОВ «Вільний», яким виключено ОСОБУ_1 із складу учасників товариства за невиконання своїх обов'язків. Постановою Донецького апеляційного господарського суду відмовлено в задоволенні позову ОСОБИ_1 про визнання недійсним рішення зборів учасників ТОВ «Вільний», яким виключено його із складу учасників товариства за невиконання своїх обов'язків. При цьому, колегією суддів встановлено, що рішення про виключення ОСОБИ_1 прийнято правомочними зборами учасників товариства, в порядку, передбаченому статутом та відповідає вимогам ст. ст. 58-61 Закону України «Про господарські товариства». Господарським судом Запорізької області зазначено, що оскільки на дату розгляду цього спору ОСОБА_1 не є учасником ТОВ «Вільний» та спір не пов’язаний з вибуттям учасника із товариства, то заявлені вимоги $є$ безпідставними та суд відмовляє у їх задоволенні. Щодо вимоги про визнання недійсною нової редакції статуту ТОВ «Вільний» в задоволенні позову суд відмовив, зазначивши таке: установчі документи господарського товариства можуть бути визнані недійсними лише 3 підстав, передбачених законодавством. 3 урахуванням положень ч. 2 ст. 110 ЦК України, підставами прийняття рішення про визнання недійсними установчих документів господарського товариства $є$ порушення закону, які не можуть бути усунуті. Оскільки за наслідками розгляду справи господарським судом не встановлено порушення прав або охоронюваних законом інтересів позивача, суд не має підстав для прийняття рішення про визнання установчих документів товариства недійсними [9].

Дії засновників з виключення учасника, як в цьому випадку, можуть бути виходом з корпоративного тупика, якщо, звісно, вони $є$ добросовісними, і не $\epsilon$ формою зловживання правом та не спрямовані на позбавлення корпоративних прав первісного засновника.

Виходом із ситуації, коли до суду потрапляє позов про виключення засновника, який володіє 50 відсотками статутного капіталу, може стати не формальний підхід судових органів - залишити все як $\epsilon$, адже закон в цьому випадку не визначає кого саме слід виключати з рівноцінних партнерів, а підхід, за якого суду треба оцінити обставини справи, визначити ступінь вини, перевірити дово- 
ди сторін. Тобто сам по собі рівний розподіл часток не може бути підставою відмови у позові.

Способом розв'язання цієї проблеми може стати встановлення в Законі про ТОВ та ТДВ чіткого переліку випадків виключення учасника товариства (навіть 3 часткою в статутному капіталі 50 відсотків). Такими обставинами можуть бути:

1) систематичне або грубе порушення засновником (учасником) своїх обов'язків;

2) якщо дії учасника унеможливлюють роботу товариства (наприклад, на його вимогу обслуговуючий банк блокує рахунки компанії, за його заявою в правоохоронні органи ними вилучено документи бухгалтерського обліку, техніка і т. п.);

3) за наявності вини в діях такого учасника, наслідком яких стало зупинення роботи товариства.

Виключення одного з учасників - це вихід з дедлоку у виняткових випадках і не може сприйматися як універсальний засіб.

Ще одним способом вирішення цієї проблеми може стати остаточне припинення корпоративних відносин між учасниками шляхом здійснення ліквідації товариства, але не завжди засновники знаходять можливість скооперуватися i здійснити цю процедуру, хоча ліквідація корпоративного підприємства може стати найбільш ефективним і зрозумілим варіантом виходу з корпоративного тупика. Так, ТОВ «Дніпрометхолдінг» звернулося до суду з позовом до ОСОБИ_1 про стягнення з останнього на свою користь суми несформованої ним частки у статутному капіталі товариства у розмірі 25750 грн, визнання недійсним рішення загальних зборів учасників ТОВ «Дніпрометхолдінг» в частині того, що частка у статутному капіталі ТОВ «Дніпрометхолдінг» у розмірі $50 \%$, яка передавалась від ОСОБИ_1 до ОСОБИ_2, є несплаченою, та в частині визначення термінів їі сплати. Позовні вимоги мотивовані тим, що до моменту державної реєстрації ТОВ «Дніпрометхолдінг», статутний капітал якого при створенні товариства визначений у розмірі 51500 грн, ОСОБОЮ_2, як одноособовим засновником товариства, внесено 50 \% його частки в статутному капіталі Товариства, що складає 25750 грн. Частка у розмірі 50 \% статутного капіталу, що залишилася несплаченою, підлягала сплаті протягом першого року діяльності товариства. 3 часом рішенням загальних зборів учасників ТОВ «Дніпрометхолдінг» до складу учасників товариства прийнято ОСОБУ_1, якому учасник товариства ОСОБА_2 вирішив переуступити частку у статутному капіталі товариства у розмірі 50 \% своєї несплаченої частки. Цим же рішенням на ОСОБУ_1 покладався обов’язок сплатити свою частку у статутному капіталі товариства, яка становить 50 \%, протягом року після державної реєстрації статуту товариства у новій редакції. Позивач посилався на ті обставини, що свої зобов'язання по формуванню статутного (складеного) капіталу товариства ОСОБА_1 не виконав, чим порушив вимоги ст. 52 Закону України «Про господарські товариства». 
ОСОБА_1 (відповідач) подав зустрічний позов до ТОВ «Дніпрометхолдінг» про: 1) визнання недійсним з моменту прийняття рішення загальних зборів учасників ТОВ «Дніпрометхолдінг» в частині того, що частка у статутному капіталі ТОВ «Дніпрометхолдінг» в розмірі $50 \%$, яка передавалась від ОСОБИ_2 до ОСОБИ_1, $є$ несплаченою, та в частині визначення термінів ії сплати; 2) визнання недійсною державної реєстрації та припинення як юридичної особи ТОВ «Дніпрометхолдінг». На думку відповідача, відчуження учасником ТОВ частки у статутному капіталі, яка несплачена, суперечить ч. 4 ст. 53 Закону України «Про господарські товариства», ч. 3 ст. 147 ЦК України. Відповідно, ОСОБА_2 не міг передати належну йому несплачену частку. ОСОБА_1 зазначав, що він фактично прийняв частку у статутному капіталі товариства, став його учасником, брав участь у діяльності товариства, що свідчить про те, що йому фактично передана сплачена частка у статутному капіталі товариства. Також, оскільки статутний капітал товариства не сформований як у встановлений законодавством строк, так і в подальшому, а зменшити статутний капітал товариства неможливо через неможливість проведення загальних зборів учасників товариства, оскільки між учасниками, кожен з яких має по 50 \% статутного капіталу, існують внутрішні протиріччя, які не можна подолати, ОСОБА_1 вбачає підстави для визнання недійсною державної реєстрації товариства та припинення товариства. При цьому ОСОБА_1 посилалася на п. 2 ч. 1 ст. 110 ЦК України, ч. 1 ст. 150 ЦК України.

Господарський суд 3'ясував, що нового учасника рішенням зборів товариства зобов'язано внести свій внесок протягом року після державної реєстрації статуту (нова редакція). Між учасниками статутний (складений) капітал розподіляється наступним чином: 1) ОСОБА_2 - 50\% статутного капіталу, що у сумі становить 25750 грн; 2) ОСОБА_1 - 50 \% статутного капіталу, що у сумі становить 25750 грн.

В судовому рішенні зазначається, що відповідно до ч. 4 ст. 53 Закону України «Про господарські товариства», ч. 3 ст. 147 ЦК України частка учасника ТОВ може бути відчужена до повної іiі сплати лише в тій частині, в якій іiі уже сплачено. Тобто рішення загальних зборів учасників Товариства у цій частині суперечить вимогам Закону України «Про господарські товариства» та ЦК України. Оскільки рішення загальних зборів учасників Товариства в частині відступлення частини частки у статутному капіталі, яка не була оплачена, суперечить вимогам закону, то відсутні підстави стверджувати про невиконання відповідачем зобов'язань перед Товариством та стягнути з відповідача за первісним позовом на користь Товариства вартість отриманої неоплаченої частини частки у статутному капіталі Товариства. Тобто заявлені позивачем вимоги про стягнення з ОСОБИ_1 на користь Товариства суми несформованої частки у статутному капіталі Товариства $є$ неправомірними та не підлягають задоволенню. 
Крім того, в судовому рішенні визначено, що не підлягають задоволенню також заявлені позивачем за зустрічним позовом вимоги про визнання недійсною державної реєстрації та припинення як юридичної особи ТОВ «Дніпрометхолдінг» в зв'язку з тим, що статутний капітал Товариства $є$ несформований у строк, встановлений законом. Відповідно до п. 2 ч. 1 ст. 110 ЦК України юридична особа ліквідується за рішенням суду про визнання судом недійсною державної реєстрації юридичної особи через допущені при ії створенні порушення, які не можна усунути, а також в інших випадках, встановлених законом. У зустрічному позові позивач не послався на жодні обставини, які б свідчили про порушення, допущені при створенні Товариства, та які не можна усунути. Недотримання вимог закону щодо оплати частини статутного капіталу, що залишилася несплаченою, протягом першого року діяльності товариства відповідно до ст. 110 ЦК України не $є$ підставою для ліквідації юридичної особи за рішенням суду [10].

Вбачається, що суд підійшов до цієї ситуації формально, не застосував таку жорстку адміністративно-господарську санкцію як ліквідація, вирішив зберегти суб'єкт господарювання і відмовив у позові на підставі норми ЦК України, яка встановлює загальні підстави ліквідації юридичної особи, тобто не став занурюватися у всі нюанси відносин учасників, вирішив не припиняти корпоративні відносини між учасниками, між якими виникли неприязні стосунки, і залишив сторони в корпоративному тупику.

Більш оптимальним виходом в подібних ситуаціях все ж таки має стати примусова ліквідація. Такий спосіб розв'язання проблеми з дедлоком розповсюджений в багатьох країнах світу. Вочевидь, цей досвід можна було б імплементувати у вітчизняне законодавство. Тим більш, відповідні положення вже частково передбачено нормами ЦК України.

Нормою п. 1 ч. 1 ст. 110 ЦК України передбачено, що юридична особа ліквідується за рішенням іiї учасників або органу юридичної особи, уповноваженого на це установчими документами 3 досягненням мети, для якої іï створено. Зараз у юридичній літературі ліквідацію за цією підставою обережно називають ні примусовою, а вимушеною [11, с. 244]. До досягнення мети можна віднести і випадки, коли здійснення діяльності корпоративного підприємства стає взагалі неможливим або надзвичайно важким. Під цю підставу припинення корпоративного підприємства може підпадати будь-який дедлок, коли учасники не мають наміру продовжувати діяльність товариства або не можуть домовитись про умови іiі здійснення. На сьогодні ця норма ЦК України не має ефективного застосування на практиці і діє радше як норма-принцип, яку треба деталізувати і уточнювати. Цю норму варто доповнити додатковою підставою для застосування ліквідації істотне утруднення діяльності товариства. Під таким станом товариства можна вважати стан, коли: 
1) учасники товариства ухиляються від участі в його діяльності, що призводить до неможливості прийняття рішень у зв'язку з відсутністю кворуму;

2) в ході тривалого корпоративного конфлікту істотні зловживання допускалися всіма учасниками товариства.

Вбачається, що така міра як примусова ліквідація може мати винятковий характер і може бути застосована лише у випадку, коли вичерпано всі інші способи розв'язання корпоративного конфлікту або якщо їх застосування неможливо.

Примусову ліквідацію як вихід з корпоративного тупика пропонується застосовувати у виняткових випадках ще й тому, що така радикальна міра тягне й суттєві несприятливі наслідки. Зокрема, всі працівники від обслуговуючого персоналу до топ-менеджерів втрачають роботу, зачіпаються інтереси контрагентів суб'єкта господарювання, учасники товариства втрачають бізнес, ділову репутацію, майно.

Але з тих же причин ліквідація є дієвим способом подолання корпоративного конфлікту. Результатом іiї є те, що серед сторін конфлікту немає тих, хто «виграв» і хто «програв», тому ліквідація може виконувати стимулюючу функцію для сторін, у яких буде мотивація прийти до консенсусу щодо збереження товариства як суб'єкта права.

Перевагою ліквідації $є$ й те, що така процедура детально регламентована законом, і учасники просто виконуватимуть приписи законодавства і не матимуть приводів для конфлікту. Крім того, після завершення процедури ліквідації може залишитися майно, яке буде розподілене між ними, і яким неможливо було скористатися в ситуації дедлока.

Ще одним (третім) способом усунення дедлоків може стати введення механізму викупу частки одним учасником у іншого під наглядом суду. Такий спосіб розв'язання дедлоків використовується в законодавстві інших країн. Він може бути затребуваний, коли учасники товариства не здатні більше приймати управлінські рішення і не можуть дійти згоди про подальшу долю компанії і варіантів спільного управління товариством, але при цьому не мають наміру ліквідувати юридичну особу і кожен готовий викупити частку опонента. Коли всі вищезазначені обставини мають місце, але сторони не можуть домовитись про ціну частки, то один з учасників може звернутися до суду з вимогою про примусовий викуп частки іншого учасника. Але задля того, щоб такий шлях вирішення проблеми став можливим, необхідно внести істотні зміни в чинне законодавство.

Запропоновані вище способи розв'язання тупикових ситуацій - це дії, які необхідно здійснювати на етапі, коли конфлікт вже наступив. Але більш оптимальним $є$ попередження конфлікту шляхом укладення корпоративного договору. 3 ним управління компанією буде більш ефективним, оскільки буде зрозумілим порядок здійснення корпоративних прав учасників, визначено способи розв'язання 
спірних ситуацій. Корпоративний договір спрямований на встановлення балансу інтересів всіх його сторін і на зменшення безпосередньо можливості настання конфліктних ситуацій в корпоративному підприємстві, а якщо ж вона все ж таки наступила - найбільш ефективний вихід з неї.

Узагальнюючи наведене вище, можна запропонувати такі напрями удосконалення законодавства щчодо способів усунення дедлока в корпоративних підприемствах:

1. Доповнення Закону про ТОВ та ТДВ новою статтею $24^{1}$ «Підстави виключення учасника з товариства» із закріпленням у ній вичерпного переліку відповідних підстав, а саме: а) систематичне або грубе порушення учасником своїх обов'язків; б) якщо дї учасника унеможливлюють роботу товариства; в) за наявності вини в діях такого учасника, наслідком яких стало зупинення роботи товариства.

2. Закріплення в ч. $1 \mathrm{~cm} .110$ ЦК України додаткової підстави для застосування ліквідації господарського товариства - істотне утруднення діяльності товариства. При цьому під таким станом товариства пропонується вважати стан, коли: а) учасники товариства ухиляються від участі в його діяльності, що призводить до неможливості прийняття рішень у зв'язку з відсутністю кворуму; б) у зв'язку з тривалим корпоративним конфліктом істотні зловживання допускалися всіма учасниками товариства.

3. Введення у вітчизняне законодавство положень щодо механізму викупу частки одним учасником у іншого під наглядом суду у разі корпоративного конфлікту.

Поряд із цим вищезазначена проблематика вимагає подальшого наукового аналізу з урахуванням доктринальних розробок і сформованої правозастосовчої практики.

1. Бігняк О. В. Захист корпоративних прав: проблеми теорії та практики: монографія. НУ ОЮА: Юридична література, 2018. 408 с.

2. Божко М. П., Галанцев Д. А. Семь уроков корпоративных конфликтов. Москва: Проспект, 2018. $96 \mathrm{c}$.

3. Вінник О.М. Корпоративна конфліктологія як новий напрямок науки господарського права. Вісник Вищзого арбітражного суду Украӥни. 2000. № 4. С. 110-114.

4. Корпоративное право: актуальные проблемы: учебник / Д. В. Ломакин, Ф. А. Афаунова, О. И. Гентовт и др.; под. общ. ред. Д. В. Ломакина. Москва: Инфотропик Медиа, 2015. 256 с.

5. Полковников Г. В. Английское право о компаниях: закон и практика: учебное пособие. Москва: «НИМП», 1999. 240 с.

6. Корпоративні спори. Коментар судової практики (Серія «Проблеми судової практики»). Спасибо-Фатєєва І. В., Крат В. І., Філатова Н. Ю. та ін.; за заг. ред. І. В. Спасибо-Фатєєвої. Харків. Право, 2018. 288 с. 
7. Цивільний кодекс України: Закон України від 16 січня 2003 р. № 435-IV. Biдомості Верховної Ради України. 2003. №№ 40-44. Ст. 356. (Із змінами).

8. Про товариства з обмеженою та додатковою відповідальністю: Закон України від 6 лютого 2018 р. № 2275-VIII. Відомості Верховної Ради Украӥни. 2018. № 13. Ст. 69. (Із змінами).

9. Рішення господарського суду Запорізької області від 23 січня 2012 р. у справі № 8/188/10. Єдиний державний реєстр судових рімень. URL: http://www.reyestr.court.gov.ua/Review/ 21398800

10. Рішення господарського суду Дніпропетровської області від 12 серпня 2010 р. у справі № K7/87-10. Єдиний державний реєстр судових рішень. URL: http://www.reyestr.court.gov.ua/ Review/10837039

11. Корпоративне право: навчальний посібник / О.В.Гарагонич, С. М. Грудницька, Л. М. Дорошенко та ін.; за заг. ред. О. В. Гарагонича, С. М. Грудницької, Л. М. Дорошенко. Київ: Видавничий дім «АртЕк», 2018. 400 с.

DOI 10.31558/2518-7953.2019.1.7

УДК 346.7

С. М. Павлюк

аспірант Донецького національного університету імені Василя Стуса

\section{ЩОДО ДОГОВІРНОГО РЕГУЛЮВАННЯ ПЕРЕВЕЗЕННЯ ВАНТАЖІВ У ПРЯМОМУ ЗМІШАНОМУ СПОЛУЧЕННІ}

Ключові слова: договір перевезення, пряме змішане сполучення, перевезення вантажів, транспортне законодавство, транспорт, перевізник, організаційний договір, вузлова угода.

Сучасний етап розвитку економіки вимагає нових оптимальних способів організації перевізного процесу за допомогою правових засобів, в якості яких виступають транспортні договори. В умовах пошуку нових логістичних підходів до доставки вантажів, забезпечення оптимальної взаємодії різних видів транспорту при здійсненні перевезень вантажів дослідження договірних відносин між учасниками перевезення вантажів у прямому змішаному сполученні стають все більш актуальними.

Як зазначається в Національній транспортній стратегії України на період до 2030 року, схваленій розпорядженням Кабінету Міністрів України від 30 травня 2018 р., транспортна система України має низький рівень розвитку інтермодальних, мультимодальних перевезень, що знижує ï конкурентоспроможність та обмежує вихід української продукції на світовий транспортний ринок. Мультимодальні та інтермодальні перевезення вантажів займають в Україні не більше 0,5 \% транспортного ринку, за цим показником Україна відстає від держав-членів СС та інших розвинутих держав світу у 20-30 разів [1]. 